\title{
ISOLATION OF MICROSPORUM GYPSEUM IN SOIL SAMPLES FROM DIFFERENT GEOGRAPHICAL REGIONS OF BRAZIL, EVALUATION OF THE EXTRACELLULAR PROTEOLYTIC ENZYMES ACTIVITIES (KERATINASE AND ELASTASE) AND MOLECULAR SEQUENCING OF SELECTED STRAINS
}

\author{
Mauro Cintra Giudice ${ }^{1,3^{*}}$, Adriana Araújo Reis-Menezes ${ }^{1}$, Glauce Mary Gomes Rittner ${ }^{1}$, Adolfo José Mota², Walderez \\ Gambale $^{1}$
}

${ }^{1}$ Instituto de Ciências Biomédicas, Departamento de Microbiologia, Universidade de São Paulo, SP, Brasil; ${ }^{2}$ Laboratório de Genética Molecular e Genomas, São José dos Campos, SP, Brasil; ${ }^{3}$ Laboratório de Bacteriologia, Laboratório de Investigação Médica/54, Hospital das Clínicas, Faculdade de Medicina, Instituto de Medicina Tropical, Universidade de São Paulo, São Paulo, SP, Brasil.

Submitted: January 20, 2011; Approved: June 07, 2012.

\begin{abstract}
A survey of Microsporum gypseum was conducted in soil samples in different geographical regions of Brazil. The isolation of dermatophyte from soil samples was performed by hair baiting technique and the species were identified by morphology studies. We analyzed 692 soil samples and the recuperating rate was $19.2 \%$. The activities of keratinase and elastase were quantitatively performed in 138 samples. The sequencing of the ITS region of rDNA was performed in representatives samples. M. gypseum isolates showed significant quantitative differences in the expression of both keratinase and elastase, but no significant correlation was observed between these enzymes. The sequencing of the representative samples revealed the presence of two teleomorphic species of M. gypseum (Arthroderma gypseum and A. incurvatum). The enzymatic activities may play an important role in the pathogenicity and a probable adaptation of this fungus to the animal parasitism. Using the phenotypical and molecular analysis, the Microsporum identification and their teleomorphic states will provide a useful and reliable identification system.
\end{abstract}

Key words: Microsporum gypseum; Brazil; Elastase; Keratinase; Sequencing.

\section{INTRODUCTION}

Microsporum gypseum is a geophilic dermatophyte, and in this group, is the main representative that affects humans and other animals $(4,21)$. The human infections are rare which may suggest a natural resistance to this infection or limited mechanisms of virulence of the fungus (12), furthermore, some outbreaks have been reported in different parts of the world (21). Atypical clinical manifestations, refractory to either topic or systemic treatments have already been described in literature in patients HIV positive, epidemiologically related to the source of geophilic infection $(10,11,24)$.

*Corresponding Author. Mailing address: Bacteriology Laboratory - LIM 54/ HCFMUSP and Institute of Tropical Medicine, University of São Paulo, São Paulo, SP, Brazil, Av. Dr. Enéas de Carvalho Aguiar, 470 São Paulo, SP. CEP 05403000, Brazil.; Tel.: +55-11-3061-7030 Fax: +55-11-30617043.; E-mail: mauro.giudice@gmail.com 
The isolation of $M$. gypseum and other geophilic dermatophytes from soil can be obtained through the hairbaiting technique (Vambreuseghem method) (19). Several reports describe the $M$. gypseum on soils with distinct characteristics in different parts of the world $(9,10,16,25,31$, 41, 44).

The dermatophytes are capable of producing enzymes as a mechanism to degrade various substrates. Several enzymes have been described and eventually correlated with dermatophytes virulence $(28,37)$, like the keratinase $(2,14,20$, $26,39,42,45)$, elastase $(2,18,33,37,42)$, DNase $(22,42)$ and collagenase $(17,23,30,32)$. The keratinase seems to have a direct relation to the pathogenicity $(13,41)$. The elastase has an important role in the pathogenicity of other fungi such as Aspergillus fumigatus $(8,20,39)$ and also, probably, to the dermatophytes $(14,17,30)$.

The objectives of this study were evaluate the frequency of M. gypseum in Brazil's soil, demonstrate quantitatively the activities of both keratinase and elastase from these isolates, and identify representative samples through the sequence to examine the distribution of the teleomorphic states.

\section{MATERIAL AND METHODS}

\section{Collection of soil samples and fungal identification}

Samples of soil from different states of Brazil were collected in the cities' public places (parks, squares, bus-stops etc.) and at peripheral regions with a spatula and transferred to a plastic bag. The fungi were isolated from the soil with the Vambreuseghem technique (19) .Macroscopic and microscopic characterization, through giant colony and microculture techniques, respectively were performed (19).

\section{Determination of the strain enzymatic profile}

The quantitative evaluation for both enzymes was made in line with the procedures previously described, with some modifications $(42,43)$. The $M$. gypseum samples were cultivated in Sabouraud dextrose broth (Oxoid) at $25^{\circ} \mathrm{C}$ for 15 days. The conidia were harvested in sterile saline, and using a Newbauer Chamber, the conidial suspension was adjusted to $1.0 \times 10^{6}$ conidia/ml.

Keratinase: One milliliter of suspension was inoculated in $50 \mathrm{ml}$ of basal medium $\left(6 \mathrm{~g} \mathrm{MgSO}_{4}, 1.0 \mathrm{ml}\right.$ Protovit vitamin mixture (Roche, São Paulo, Brazil), 0,111 g CaCl 2 , in $1000 \mathrm{ml}$ distilled water) with $3 \mathrm{~g}$ keratin powder from hooves and horns (ICN, Montreal, Canada) and incubated at $25^{\circ}$ for 28 days in the dark $(36,43)$. One milliliter of $1500 \mathrm{~g}$ centrifuged culture supernatant was then mixed with $2 \mathrm{ml}$ of buffer 200 $\mathrm{mM}$ Tris-HCI, $\mathrm{CaCl}_{2} 100 \mathrm{mM}$, pH 8.0 plus $10 \mathrm{mg}$ of Keratin Azure (Sigma, St. Louis, MO, USA) plus $2.0 \mathrm{~mL}$ of and afterwards incubated at $37^{\circ} \mathrm{C}$ for $24 \mathrm{~h}$. Substrate degradation was measured in a spectrophotometer at $595 \mathrm{~nm}$ using uninoculated substrate buffer as a negative control. A keratinase unit (UK) was defined as an increase of 0.01 in the absorbance, when compared to the control.

Elastase: One milliliter of adjusted suspension was inoculated in $50 \mathrm{~mL}$ of the same basal medium with $3.0 \mathrm{~g}$ of elastin (Sigma St. Louis, MO, USA) and incubated at $25^{\circ} \mathrm{C}$ for 28 days in the dark (43). Two milliliters of $1500 \mathrm{~g}$ centrifuged culture supernatant was then mixed with $2.0 \mathrm{~mL}$ of phosphate buffer $(10 \mathrm{mM} \mathrm{pH}, 7.0)$ with $20 \mathrm{mg}$ of Elastin Congo-Red (Sigma St. Louis, MO, USA) was incubated at $37^{\circ} \mathrm{C}$ for 2 hours. The elastin degradation was evaluated by spectrophotometer in $495 \mathrm{~nm}$ wavelength. A unit of elastase (UE) was defined as the 0.1 increase in the absorption reading, when compared to the control.

\section{DNA extraction}

Extraction protocol was modified from Bir et al., 1995 (5), with some modifications. M. gypseum samples were incubated in Sabouraud broth medium for 14 days at $25^{\circ} \mathrm{C}$ and the mycelia was powdered with liquid nitrogen and $3.0 \mathrm{~mL}$ of 10 $\mathrm{mM}$ phosphate buffer $\mathrm{pH}$ 6.0. Volumes of $20 \mu \mathrm{L}$ chitinase $(5 \mathrm{U} / \mathrm{mL})$ (Sigma) were added and it was incubated for 90 minutes at $25^{\circ} \mathrm{C}$ temperature, shaking it many times. Equal volume of lysis buffer (50 mM Tris $\mathrm{HCl}, 50 \mathrm{mM}$ EDTA, 3\% SDS, $1 \% \beta$-mercaptoethanol, $\mathrm{pH}$ 7.2) was added and the suspension was incubated at $55^{\circ} \mathrm{C}$ for one hour, shaking it many times. The products were then subjected to heat treatment in a microwave oven for 3 seconds each for 3 times. 
Extraction with phenol:chloroform:isoamylalcohol $(25: 24: 1)$ was performed and the DNA was precipitated with isopropyl alcohol at $-20^{\circ} \mathrm{C}$ for about 18 hours. DNA was washed with $70 \%$ ethanol and it was dried at environment temperature, rehydrated in $25 \mu \mathrm{L}$ of TE buffer $(10 \mathrm{mM}$ Tris- $\mathrm{HCl}, 1 \mathrm{mM}$ EDTA, pH 8.0) with RNase $(10 \mu \mathrm{g} / \mathrm{mL})$ and it was incubated in a dry bath for 30 minutes at $37^{\circ} \mathrm{C}$. The product was again drawn up with isoamilic phenol-chloroform-alcohol and the DNA was dissolved in $50 \mu \mathrm{L}$ of sterile ultrapure water. The DNA concentration was determined spectrophotometrically. Quality of the DNA was evaluated by agarose $0.8 \%$ in TAE buffer (1X) gel electrophoresis and stained with ethidium bromide. The visualization for confirmation of the extraction was done in the chamber of the GEL DOC 1000 equipment under ultraviolet rays (Bio-Rad).

\section{PCR amplification}

The amplification of the conserved regions of rDNA (ITSPCR Internal Transcribed Spacers - Primer Chain Reaction) was performed with a pair of primes ITS1 (5', TCCGTAGGTGAACCTGCGG 3'), and ITS 4 (5' TCCTCCGCTTATTGATATGC 3') (6).

The mixture for a PCR was prepared in total volume of 25 $\mu \mathrm{L}$ containing the reaction buffer $(10 \mathrm{mM}$ Tris- $\mathrm{HCl}$ in $\mathrm{pH} 8.0$, $50 \mathrm{mM}$ of $\mathrm{KCl}, 1.5 \mathrm{mM}$ of $\mathrm{MgCl}_{2} 10 \mathrm{mM}$ of each DNTP (Fermentas, USA), $0.125 \mu \mathrm{M}$ of each primer, $2 \mathrm{U}$ of Taq Polimerase and $50 \mathrm{ng}$ of DNA). The amplification was performed in thermocycler (PTC - 100, MJ Research, INC.) on the following conditions: $94^{\circ} \mathrm{C}, 5 \mathrm{~min}\left(94^{\circ} \mathrm{C} 1 \mathrm{~min}, 56^{\circ} \mathrm{C} 30 \mathrm{~s}\right.$, $72^{\circ} \mathrm{C} 1 \mathrm{~min}$.) per 25 cycles and final extension at $72^{\circ} 5 \mathrm{~min}$.

\section{Sequencing}

Five specimens (three from Rondônia and two from São Paulo states) were arbitrarily selected to the sequencing. These isolates were chosen because they represent respectively the most sampled state (RO) and state where we have had the highest recuperating rate (SP) of Microsporum gypseum . After amplification, the PCR products were purified using QIAquick Spin Columns (Qiagen Corp.., Chatsworth, Calif.), and were reconstituted with $30 \mu \mathrm{L}$ of distilled water. The sequencing was carried out in platforms for dna sequencing PDTIS, which we used Big Dye reagent (Applied Biosystem, Foster City CA, USA) and automated sequencer Applied Biosystems ABI Prism 3730 (Applied Biosystem, Foster CA, USA).. The sequences were submitted to a search on the BLASTn by using the databank of the National Center of Biotechnology (NCBI; http://www.ncbi.nlm.nih.gov/BLAST).

\section{RESULTS}

The soil samples were collected from all Brazilian regions. The largest Microsporum gypseum positivity percentual was obtained from the samples originated in the Southeast (SE), followed by the North (N), Southern (S) and Center-West (CW). In Northeast region, in the states evaluated, there was no isolation of M. gypseum (Table 1, Fig. 1). The number of soil samples collected was differed in each region, as well as the positivity percentage. In total, 692 soil samples were analyzed and the recuperating rate was $19.2 \%$. In samples from some states it was not possible to obtain growth of M. gypseum (Bahia, Tocantins, Maranhão, Ceará and Rio de Janeiro). The state of São Paulo demonstrated larger fungus recuperation from the soil samples, proportionally, with a recuperating rate of $44.7 \%$. The state of Rondônia contributed with the largest number of soil samples, but the recuperating rate was only $20.4 \%$ (Table 1 , Fig. 1).

The evaluation of both the elastinolytic and keratinolytic activities was performed in Microsporum gypseum $(\mathrm{n}=121)$ isolated from the soil from different states. The means and the standard deviations of the two enzymatic activities (UK and UE) were $6.90 \pm 8.48$ to $\mathrm{UK}$ and $1.60 \pm 2.20$ to UE. The median were 5.0 UK and 0.92 UE

The results of absolute and relative frequencies from both enzymatic activities for 121 samples of M. gypseum, are showed on Fig. 2 ( $a$ and $b$ ).

The Spearman's coefficient of correlation from two enzymatic activities (UK and UE) was very weak. In soils samples the coefficient of correlation was -0.014 , a low 
negative, which suggests the absence of correlation among the enzymatic activities.

The sequencing of the representative samples revealed the presence of two teleomorphic species of $M$. gypseum (Arthroderma gypseum and A. incurvatum) and A. incurvatum was identified in only one of the isolated.

Table 1. Distribution of the number of analyzed samples of soil, absolute and relative frequencies of recuperation by administrative region and by States of the Federation of Brazil.

\begin{tabular}{|c|c|c|c|c|}
\hline Regions & States & $\begin{array}{c}\text { Number of soil } \\
\text { samples }\end{array}$ & $\begin{array}{c}\text { Number of positive } \\
\text { samples }\end{array}$ & $\%$ of positivity \\
\hline $\mathrm{NE}$ & Bahia & 8 & 0 & 0 \\
\hline $\mathrm{NE}$ & Maranhão & 56 & 0 & 0 \\
\hline $\mathrm{NE}$ & Ceará & 11 & 0 & 0 \\
\hline \multicolumn{2}{|c|}{ Subtotal Northeast region } & 75 & 0 & 0 \\
\hline $\mathrm{N}$ & Tocantins & 4 & 0 & 0 \\
\hline $\mathrm{N}$ & Pará & 34 & 7 & 20.6 \\
\hline $\mathrm{N}$ & Rondônia & 201 & 41 & $20 ., 4$ \\
\hline \multicolumn{2}{|c|}{ Subtotal North region } & 239 & 48 & 20.1 \\
\hline $\mathrm{CO}$ & Mato Grosso & 4 & 1 & 25 \\
\hline $\mathrm{CO}$ & Mato Grosso do Sul & 30 & 1 & 3.33 \\
\hline $\mathrm{CO}$ & Goiás & 55 & 6 & 10.9 \\
\hline \multicolumn{2}{|c|}{$\begin{array}{l}\text { Subtotal } \\
\text { Central West region } \\
\end{array}$} & 89 & 8 & 9.0 \\
\hline $\mathrm{SE}$ & Rio de Janeiro & 15 & 0 & 0 \\
\hline $\mathrm{SE}$ & São Paulo & 76 & 34 & 44.7 \\
\hline SE & Espírito Santo & 19 & 5 & 26.3 \\
\hline SE & Minas Gerais & 45 & 14 & 31.1 \\
\hline \multicolumn{2}{|c|}{$\begin{array}{l}\text { Subtotal } \\
\text { Southweast region }\end{array}$} & 155 & 53 & 34.2 \\
\hline $\mathrm{S}$ & Rio Grande do Sul & 66 & 14 & 21.2 \\
\hline S & Paraná & 38 & 6 & 15.8 \\
\hline$\underline{S}$ & Santa Catarina & 30 & 4 & 13.3 \\
\hline \multicolumn{2}{|c|}{ Subtotal South region } & 134 & 24 & 18.0 \\
\hline \multicolumn{2}{|c|}{ TOTAL } & 692 & 133 & 19.2 \\
\hline
\end{tabular}

NE - Northeast; N - North; CO - Central West; SE - Southeast; S - South

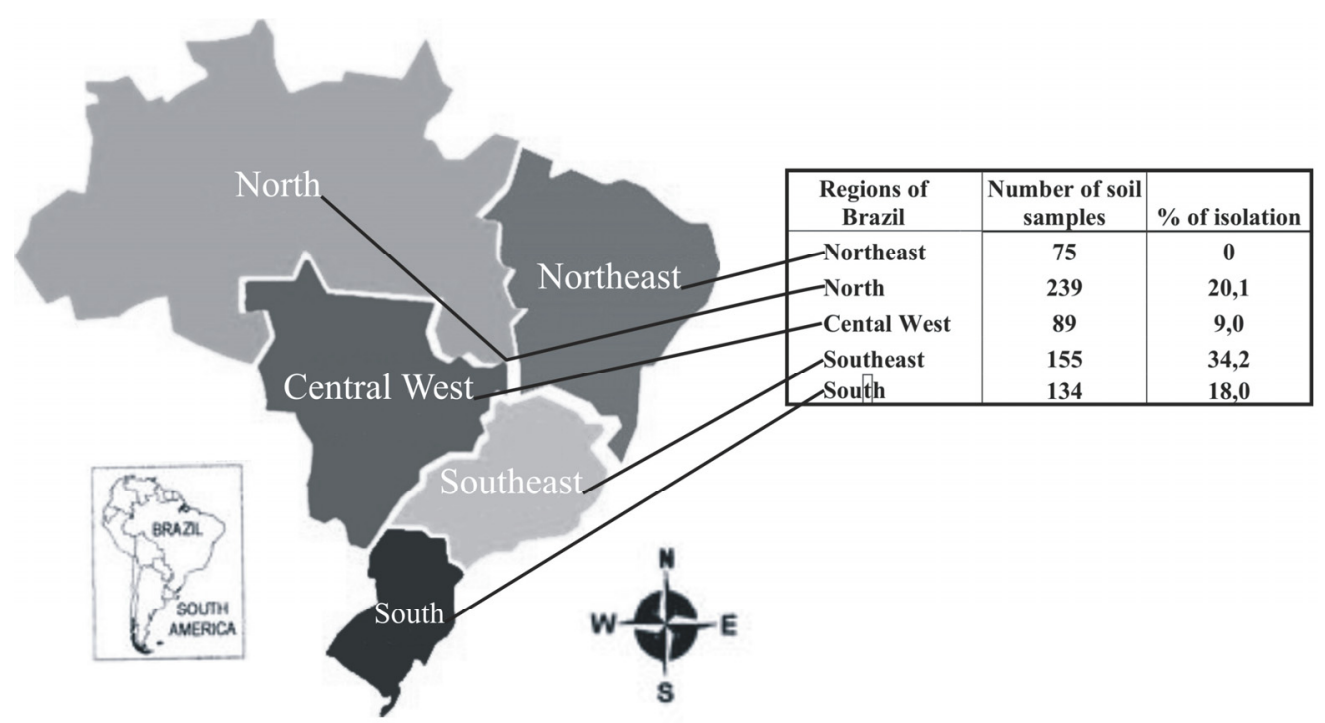

Figure 1. Number of soil samples analyzed and its percentage of isolation of Microsporum gypseum by administrative region of Brazil. 


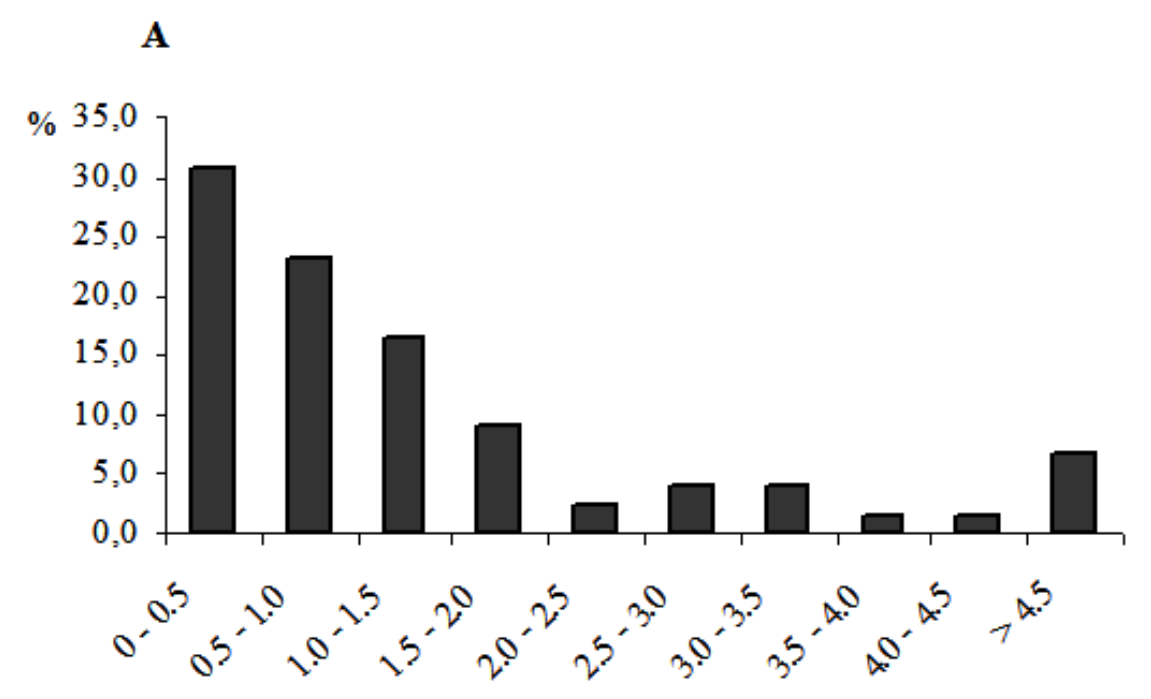

UE intervals

$\mathbf{B}$

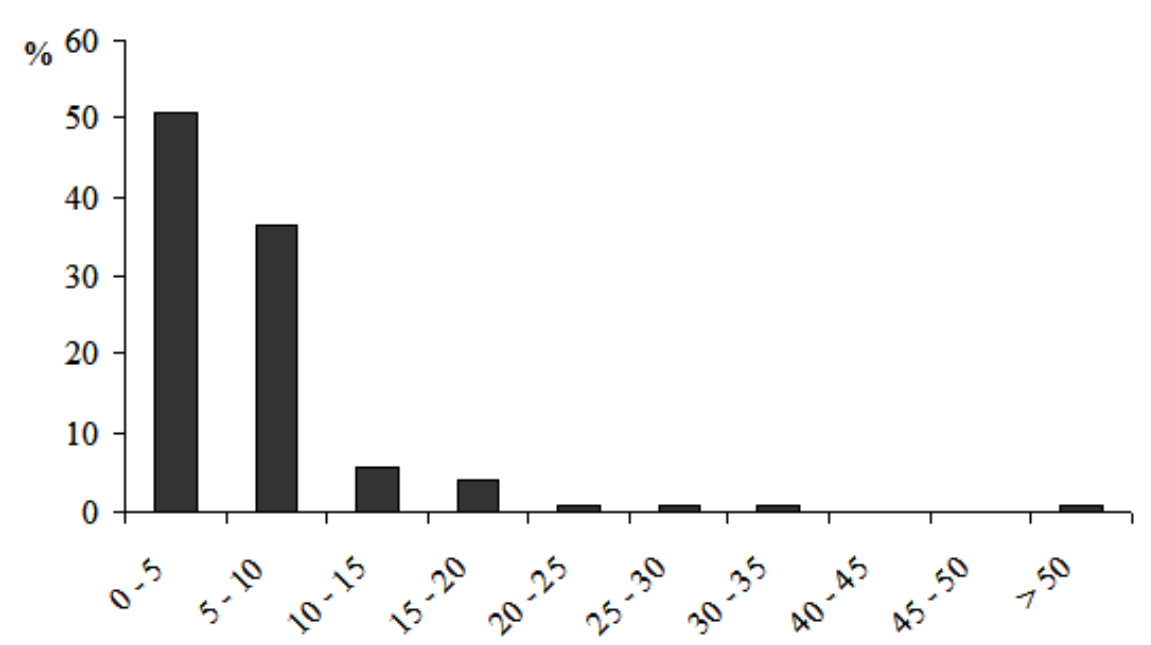

UK intervals

Figure 2. Percentual distribution of elastinolytic activity (UE - unit of elastase) (a) and keratinolytic activity (UK - unit of keratinase) (b), in Microsporum gypseum strains ( $\mathrm{n}=121)$ isolated from soils of different geographical regions of Brazil.

\section{DISCUSSION}

The isolation of $M$. gypseum can be obtained from human clinic sources, as well as from veterinarian or from the soil. The recuperating rate of this dermatophyte in clinic cases is very limited (21). However, reports of outbreaks, extensive cases and refractory therapeutics are already presented by the literature $(10,21)$. In this research, 692 samples of soil of different Brazilian regions were evaluated and the recuperating rate was $19.2 \%$. Microsporum gypseum was isolated in almost all sampled regions, except for the Northeast. The great majority of the samples were collected both in urban environments and public parks places (parks and squares), at random and in different times of the year. The absence of homogeneity in the sampled areas and in the collecting period makes it difficult to compare the analyzed areas.

In the Northeast, a very extensive geographic area, which comprises different type of soil and population distribution variable, a more thorough study, must be done studying soil from all states in different seasons of the year, considering 
local environmental variables.

Some studies demonstrate that the recuperation of this fungus can change with the sampled environment. When one evaluates either public areas of both parks or public squares or areas of confinement of animals (breeding, slaughtering and zoos) the isolating rates may be very high, differently from those found in closed environments (domestic or hospital) (4, $9,16,21,25,31,41,44)$.

Both the synthesis and the enzymes secretion are important metabolic activities in filamentous fungi and their production is an indispensable condition to the fungi's development (1). Proteolytic enzymes, such as the keratinases, collagenases and elastases are important in various processes, some of that are implicated in the pathogenesis of fungal diseases, thereby causing damages to the host's tissue $(2,14$, $34,42)$.

The dermatophytes can produce various proteolytic enzymes and their lythic activities on different substrates, have already been described (3, 7, 8, 15, 17, 27, 29, 33, 36, 40, 42). The keratinase, among other enzymes, was considered as a virulence factor, which correlated with clinic forms of dermatophytosis (13).

In M. gypseum, T. mentagrophytes, T. verrucosum, Muhsin et al. (27) demonstrated the presence of elastase. However, the elastinolytic activity was not observed in strains of M. canis.

The data obtained from this work refer to the first report in the literature on hydrolytic enzymes activities in samples of Microsporum gypseum isolated from Brazilians soil samples,

This research was made to evaluate the degree of correlation as well as the description of both keratinase and elastase activities. The results suggested that the expressions of these enzymes, which are produced by M. gypseum, occur in samples isolated from environmental fonts.

The mean and median values obtained were higher in the keratinolytic activity than in the elastinolytic one.

In strains isolated from soil originated in 16 Brazil's different geographic regions, the larger intensity of keratinolytic activity occurred in one samples (sample 19, with
77.7 UK) and the same occurred to the elastinolytic activity (sample 26, with 12.85 UE), both recuperated in São Paulo state, but from different places. The correlation grade, however, was both low and negative between the two enzymatic activities evaluated.

More detailed studies with the samples that showed high grade of enzymatic activities and with other samples with low enzymatic activities must be performed, including both experimental infection and evaluation of the tissue compromise, with the intention of evaluating the host's compromising degree with the fungus and their metabolites.

In a previous study, which was performed to quantitatively evaluate both the keratinolytic and elastinolytic activities in M. canis, strains isolated from animals with and without clinic lesion, the results showed statistically significant differences, suggesting that the elastase like the keratinase, can influence the tissue reactions in the dermatophytosis (6).

There was no correlation among the strains with the production of each enzyme, suggesting that there is not only a proteinase with keratinolytic, elastinolytic activities, but specific enzymes to each substrate. Brouta et al. (7) demonstrated that two described proteases can exert activity on the keratin, the elastin and collagen by suggesting that these two proteases should be responsible for the observed keratinase, elastase and collagenase activities.

The differentiation among six species of the Microsporum, based on the characterization of ITS of rDNA region, was evaluated, demonstrating to be sufficient to separate them $(35,38)$ and, despite the fact that the Microsporum gypseum is endemic in different parts of the world, few studies of molecular analysis have been performed in this specie.

Molecular methods based on the rDNA amplification and associated with the enzymatic restriction have been used both to differentiate species and to biotype microorganisms $(14,35)$. The use of different restriction enzymes has afforded results which, when associated with phenotypic characteristics, can help the identification of isolated ones (7).

The PCR-RFLP with Mval enzyme in Microsporum 
species has often been used. Sharma et al. (35), when using the RFLP sequencing of the ITS region of rDNA plus phenotypic described a new taxon, Microsporum appendiculatum which is highly related to $M$. gypseum.

In our study, when evaluated the sequencing, a high identity was noted, showing that the ITS region is highly preserved in this specie. The sequencing revealed the presence of two teleomorphic species of M. gypseum (Arthroderma gypseum and $A$. incurvatum). Despite the fact that only few samples have been sequenced, A. incurvatum was identified in one of the isolated. The obtaining of the teleomorphic stage in vitro and the characterization of the species are very time consuming and, in the great majority, the results depend upon a very accurate morphological evaluation. Therefore the molecular methods of sequencing are promising.

In spite of the fact that the asexual reproduction among the dermatophytes is much more frequent than the sexual reproduction, constituting their principal way propagation, the molecular methods utilized here are still limited to characterize differences in these isolated and, possibly, the expression of the enzymatic activities must be related to genotypes not yet characterized by the techniques used in this study.

Geophilic dermatophytes are very common in Brazil soils and the relationship between the characterization based on morphological, biochemical and molecular aspects seems to be very important in demonstrate the real role in its pathogenicity. However, this fungal and its biological relationship requires to be better clarified once these fungi are found as human and veterinarian pathogens causing distinct clinic manifestations that are sometimes refractory to the available treatments at present.

\section{ACKNOWLEDGEMENTS}

We are grateful to the financial Foundation of Research Support of São Paulo - Program for Centers of (FAPESPPRONEX), National Council for Scientific and Technological (CNPq) and the group of Biomedical Center of University of São Paulo in Monte Negro (RO), Brazil.

\section{REFERENCES}

1. Alvarez, D.P.; Luque, A.G.; Bracalenti, B.C. (1986). La influencia de factores ecológicos in el aislamento de dermatofitos queratinolíticos y geofílicos. Rev. Latinoam. Microbiol. 28, 351-354.

2. Apodaca, G; Mckerrow J.H. (1989). Purification and characterization of a 27,000 - Mr extracelullar proteinase from Trichophyton rubrum. Infect. Immun. 57(10), 3072-3080.

3. Aubaid, A.H.; Muhsin, T.M. (1998). Partial purification and kinetic studies of exocellular proteinase from Trichophyton mentagrophytes var. erinacei. Mycoses. 41, 163168.

4. Bársena-Asensio, .M.C.; Cabo, J.F.G. (1996). Ecología de los dermatofitos. Rev. Iberoam. Micol. 13(2), 47-54.

5. Bir, N.; Paliwal, A.; Muralidhar, K.; Reddy, P.; Usha-Sarma, P. (1995) A rapid method for the isolation of genomic DNA from Aspergillus fumigatus. Prep. Biochem. 25(4), 171-181.

6. Blanz, P.; Buzia, W.; Ginter, G.; Gräser, Y. (2000). Molekularbiologische methoden und ihre konsequenzen für taxonomie und diagnostik dei dermatophyten. Mycoses. 43(suppl. 1), 11-16.

7. Brouta, F.; Descamps, F.; Feti, T., et al. (2001). Purification and characterization of a $43.5 \mathrm{kDa}$ keratinolytic metalloprotease from Microsporum canis. Med. Mycol. 39, 269-275.

8. Chattaway, F.W.; Ellls, D.A.; Barlow, E.J. A.( 1963). Peptidases of Dermatophytes. The J. Invest. Dermatol. 41(1), 31-37.

9. Deshmukh, S.K. (2004). Isolation of dermatophytes and other keratinophilic fungi from the vicinity of salt pan soils of Mumbai, India. Mycopathologia.157:265-267.

10. Fernandes, N.C.; Lamy, F.; Akiti, T.; Da Barreiros, M.G.C. (1998). Microsporum gypseum infection in AIDS patient: a case report. An. Bras. Dermatol. 73, 39-41.

11. Giudice, M.C.; Szeszs, M.W,; Scarpini, R.L. et al.(1997). Clinical and epidemiological study in an AIDS patient case with Microsporum gypseum infection. Rev. Iberoam. Micol. 14(4), 184-187.

12. Gordon, M.A.; Perrin, N.; Little, G.N. (1967). Differences in pathogencit between M. gypseum and M. fulvum. Sabouraudia.5,366390.

13. Grappel, S.F.; Blank, F. Role of keratinase in dermatophytosis. (1972). Dermatologica. 145, 245-255.

14. Gupta, R.; Ramnani, P. (2006) Microbial keratinases and their prospective applications: an overview. Appl. Microbiol. Biotechnol. 70, 21-33.

15. Hamaguchi, T.; Morishita, N.; Usui, R.; Takiuchi, I. (2000). Characterization of an extracellular keratinase from Microsporum canis. Japanese J. Med. Mycol. 41, 257-262.

16. Hedayat, M.T.; Mohseni-Bandpi, A.; Moradi, S. ( 2004). A survey on the pathogenic fungi in soil samples of potted plants from Sari hospitals, Iran. J. Hosp. Infect. 58 (1), 59-62.

17. Ibrahim-Granet, O.; Hernandez, F..; Chevrier, G.; Dupont, B. (1996) 
Expression of PZ-peptidases by cultures of several pathogenic fungi. Purification and characterization of a collagenase from Trichophyton schoenleinii. J.Med. Vet. Mycol. 34, 83-90.

18. Kothary, M.H.; Chase, T.; Macmillan, J.D. (1984) Correlation of elastase production by strain of Aspergillus fumigatus with ability to cause pulmonary invasive aspergillosis in mice. Infect. Immun.43(1), 320325.

19. Lacaz, C.S.; Porto, E.; Martins, J.E.C.; Heins-Vaccari, E.M.;, Melo, N.T. (2002) Tratado de Micologia Médica. 9th ed. Sarvier, São Paulo, 2002.

20. Lee, K.H.; Park, K.K.; Park, S.H.; Lee, J.B. (1987). Isolation, purification and characterization of keratinolytic proteinase from Microsporum canis. Yonsei Med. J. 28(2), 131-138.

21. Londero, A.T.; Ramos, C.D. (1989). Agentes de dermatofitoses humanas no interior do Estado do Rio Grande do Sul, no período de 1960-1987. An. Bras. Dermatol. 64(3), 161-164.

22. Lópes-Martinez, R.; Manzano-Gayosso, P.; Mier, T.; Mendez-Tovar, L.J.; Hernández-Hernández, F. (1994). Exoenzimas de dermatofitos aislados de tiñas agudas y crônicas. Rev. Latinoam. Microbiol. 36, 1720.

23. Lupan, D.M.; Nziramasanga, P. (1986). Collagenolytic Activity of Coccidioides immitis. Infect. Immun. 51(1), 360-361.

24. Luque, A.G.; Biasoli, M.S.; Ortino, M.A.; Lupo, S.H.; Bussy, R.F. (2001). Atypical tinea corporis caused by Microsporum gypseum in a subject with acquired immune deficiency syndrome. J. Eur. Acad. Dermatol. Venereol.15, 374-375.

25. Mercantini, R.; Marsella, R.; Cervellati, M.C. (1989).Keratinophylic fungi isolated from Antartic soil. Mycophatologia.106, 47-52.

26. Mignon, B.R.; Nikkles, A.F.; Piérard, G.E.; Losson, B.J. (1998). The in vitro and in vivo production of a $31.5 \mathrm{kDa}$ keratinolitic subtilase from Microsporum canis and the clinical status in naturally infected cats. Dermatology.196, 438-441.

27. Muhsin, T.M.; Aubaid, A.H.; Al-Duboon, A.H. (1997). Extracellular enzyme activities of dermatophytes and yeast isolates on solid media Mycoses. 40, 465-469.

28. Muhsin, T.M.; Salih, T.H. (2001). Exocellular enzyme activity of dermatophytes and other fungi isolated from ruminants in Southern Iraq Mycopathologia.150(2), 49-52.

29. Okafor, J.; Ngwogu, A. (2000). Keratinolytic activity of five human isolates of dermatophytes. J. Commun. Dis. 32(4), 300-305.

30. Okeke, C.N.; Müller, J. (1991). Production of extracellelar collagenolytic proteinases by Histoplasma capsulatum var. duboisii and Histoplasma capsulatum var. capsulatum in the yeast phase. Mycoses. 34, 453-460.

31. Periasamy, A.; Hilda, A.; Gopinath, S.C.B. (2004). Keratinophilic fungi of poultry farm and feather dumping soil in Tamil Nadu, India. Mycopathologia.158, 303-309.

32. Rippon, J.W.; Varadi, D.P. (1968). The elastases of pathogenic fungi and actinomycetes. The J. Invest. Dermatol. 50(1), 54-58.

33. Rippon, J.W. (1967). Elastase production by ringworm fungi. Science.157, 947.

34. Scott, J.A,.; Untereiner, W.A. (2004). Determination of keratin degradation by fungi using keratin azure. Med. Mycol. 42, 239-246.

35. Sharma, R.; Rajak, R.C.; Pandey, A.K.; Gräser, Y. (2006)Internal Transcribed Spacer (ITS) of rDNA of appendaged and non-appendaged strains of Microsporum gypseum reveals Microsporum appendiculatum as its synonym. Antonie van Leeuwenhoek. 89(1), 197-202.

36. Siesenop, U.; Bohm, K. H. (1995). Comparative studies on keratinase production of Trichophyton mentagrophytes strains of animal origin. Mycoses.38, 205-209.

37. Simpanya, M.F.; Baxter, M. (1996). Multiple proteinases from two Microsporum species. J. Med. Vet. Mycol. 34, 31-36.

38. Summerbel, R.C.; Moore, M.K.; Starink-Willemse, M.; Van Iperen, A. (2007) ITS barcodes for Trichophyton tonsurans and T. Equinum. Med. Mycol. 45, 193-200.

39. Takiuchi, I.; Higuchi, D.; Sei, Y.; Koga, M. (1982). Isolation of an extracellular proteinase (keratinase) from Microsporum canis. Sabouraudia. 20, 281-288.

40. Takiuchi, I.; Youshihiro, S.; Hisae, T.; Makoto, N. (1984). Partial characterization of the extracelular keratinase from Microsporum canis. Sabouraudia. 22(3), 219 - 224.

41. Ulfig, K.; Plaza, G.; Sztyler, A.; Bronder, J.; Terakowiski, M.; Guarro, J. (2000) General assessment of the influence of a municipal landfill site and environmental factors on the occurrence of keratinolytic fungi in soil. Rocz. Panstw. Zakl. Hig. 51(2), 167-81.

42. Viani, F.C.; Dos Santos, J.I.; Paula, C.R.; Larsson, C.E.; Gambale, W. (2001) Production of extracellular enzymes by Microsporum canis and their role in its virulence. Med. Mycol. 39 (5), 463-468.

43. Viani, F.C.; Viani, P.R.C.; Rivera, I.N.G.; Silva, E.G.; Paula, C.R.; Gambale, W. (2007). Extracellular proteolytic activity and molecular analysis of Microsporum canis strains isolated from symptomatic and asymptomatic cats. Rev. Iberoam. Micol. 24(1), 19-23.

44. Vidyasagar, G.M.; Narayan, H.; Shivkumar, D. (2005) Keratinophilic fungi isolated from hospital dust and soils of public places at Gulbarga, India. Mycopathologia.159, 13-21.

45. Yu, R.J.; Harmon, S.R, (1968). Isolation and purification of an extracellular keratinase of Trichophyton mentagrophytes. J. Bacteriol. 96(4), 1435-1436. 